\title{
Transforming growth factor beta (TGF $\beta$ ) signaling is regulated at the pocket region of primary cilia
}

\author{
S Christensen ${ }^{1 *}$, CA Clement ${ }^{1}$, SK Brorsen ${ }^{1}$, KD Ajbro², M de Jesus ${ }^{1}$, LB Pedersen ${ }^{1}$, LA Larsen² \\ From First International Cilia in Development and Disease Scientific Conference (2012) \\ London, UK. 16-18 May 2012
}

TGF $\beta$ signaling extensively cross-talks with Hh, Wnt and RTK signaling to control cell proliferation, migration and differentiation, and when aberrantly regulated leads to developmental defects and cancer. TGF $\beta$ signaling is activated through the internalization of TGF $\beta$ receptors via clathrin-dependent endocytosis (CDE), at which the receptor activates Smad transcription factors. Here we investigated the relationship between TGF $\beta$ signaling and primary cilia in fibroblasts and in EC and human embryonic stem cells during their differentiation into cardiomyocytes and neurons using transcriptomics, imaging and molecular biology tools. During cardiomyocyte differentiation, expression of TGF $\beta$ receptors and Smad proteins were up-regulated and targeted to the pocket region of primary cilia, at which the receptor colocalized with clathrin-coated pits and vesicles to activate Smad2/3. This activation was blocked by receptor antagonists or by Ift 20 knockdown. In contrast, neuronal differentiation was associated with a loss of ciliary TGF $\beta$ signaling. In mouse embryonic fibroblasts (MEFs) and human foreskin fibroblasts (hFFs), TGF $\beta$ stimulation increased the targeting of TGF $\beta$ receptors to the ciliary pocket region followed by activation of Smad signaling to promote cell cycle entry. In Tg737orpk MEFs there was a major reduction in TGF $\beta$ induced Smad2/3 phosphorylation, and this was associated with reduced activity of clathrin-dependent endocytosis at stumpy primary cilia. Similarly, inhibition of CDE blocked activation of Smad2/3 at the ciliary pocket region in hFFs. Our results suggest that the ciliary pocket region functions as a unique site for regulation of TGF $\beta$ signaling and potentially in cross-talking with other signaling pathways during development and in tissue homeostasis.

* Correspondence: stchristensen@bio.ku.dk

${ }^{1}$ Department of Biology, University of Copenhagen, Denmark

Full list of author information is available at the end of the article

\section{Author details}

${ }^{1}$ Department of Biology, University of Copenhagen, Denmark.

${ }^{2}$ Wilhelm Johannsen Centre for Functional Genome Research, University of Copenhagen, Denmark.

Published: 16 November 2012

doi:10.1186/2046-2530-1-S1-O23

Cite this article as: Christensen et al:: Transforming growth factor beta (TGF $\beta$ ) signaling is regulated at the pocket region of primary cilia. Cilia 2012 1(Suppl 1):O23.

Submit your next manuscript to BioMed Central and take full advantage of:

- Convenient online submission

- Thorough peer review

- No space constraints or color figure charges

- Immediate publication on acceptance

- Inclusion in PubMed, CAS, Scopus and Google Scholar

- Research which is freely available for redistribution
C Biomed Central

C 2012 Christensen et al; licensee BioMed Central Ltd. This is an Open Access article distributed under the terms of the Creative Commons Attribution License (http://creativecommons.org/licenses/by/2.0), which permits unrestricted use, distribution, and reproduction in any medium, provided the original work is properly cited. 